\title{
PENGARUH DEBT TO EQUITY RATIO (DER) TERHADAP MARKET TO BOOK RATIO (MBR) PADA PERUSAHAAN SUB SEKTOR PERDAGANGAN BESAR BARANG PRODUKSI YANG TERCATAT DI BURSA EFEK INDONESIA
}

\author{
Oleh: \\ Astuti \\ S1 Akuntansi \\ Pinondang Nainggolan, Rosanna Purba, Jubi
}

Abtraksi

Tujuan dari penelitian ini adalah untuk mengetahui gambaran Debt to Equity Ratio (DER) dan Market to Book Ratio (MBR) serta untuk mengetahui dan menganalisis signifikansi pengaruh Debt to Equity Ratio (DER) terhadap Market to Book Ratio (MBR) pada Perusahaan Sub Sektor Perdagangan Besar Barang Produksi yang tercatat di Bursa Efek Indonesia. Penelitian ini dilakukan dengan menggunakan metode analisis deskriptif kualitatif dan analisis deskriptif kuantitatif. Objek penelitian adalah Perusahaan Sub Sektor Perdagangan Besar Barang Produksi yang tercatat di Bursa Efek Indonesia tahun 2009 sampai dengan tahun 2013 yang telah memenuhi kriteria yaitu sebanyak 24 perusahaan. Pengumpulan data dilakukan dengan metode dokumentasi. Teknik analisis yang digunakan adalah regresi linier sederhana, koefisien korelasi, determinasi dan uji t. Analisis data dilakukan dengan menggunakan bantuan software statistic SPSS 21.

Hasil penelitian dapat disimpulkan sebagai berikut: 1) Rata-rata Debt to Equity Ratio (DER) adalah sebesar 1,82. 2) Rata-rata Market to Book Ratio (MBR) adalah sebesar 1,789. 3) Ada pengaruh positif antara Debt to Equity Ratio (DER) terhadap Market to Book Ratio (MBR). 4) Hipotesis penelitian $\mathrm{H}_{0}$ diterima artinya Debt to Equity Ratio (DER) berpengaruh tidak signifikan terhadap Market to Book Ratio (MBR). 5) Terdapat hubungan yang sangat lemah antara Debt to Equity Ratio (DER) terhadap Market to Book Ratio (MBR) sebesar 0,181.6) Terdapat pengaruh yang tidak signifikan antara Debt to Equity Ratio (DER) terhadap Market to Book Ratio (MBR) pada Perusahaan Sub Sektor Perdagangan Besar Barang Produksi yang tercatat di Bursa Efek Indonesia yaitu sebesar 3,3 persen.

Kata Kunci: Debt to Equity Ratio (DER) dan Market to Book Ratio (MBR)

Abstract

The purpose of this research are to describe the Debt to Equity Ratio (DER) and the Market to Book Ratio $(M B R)$ and to know and to analyze the significance influence of the Debt to Equity Ratio (DER) towards the Market to Book Ratio (MBR) on the Company's Sub Sector Major Trade Goods Production which is listed on the Indonesia Stock Exchange. This research was done by using descriptive analysis method of qualitative and quantitative descriptive analysis. Object of this research is the Company's Sub Sector Major Trade Goods Production which is listed on the Indonesia Stock Exchange in 2009 up to the year 2013 who have met the criteria of as many as 24 companies. Data collection was carried out with methods of documentation. Analytical techniques used are simple linear regression, correlation coefficient, determination, and t-test. Data analysis was done using SPSS statistics software assistance 21.

The results of this research can be concluded as: 1) Mean of the Debt to Equity Ratio (DER) is 1.82. 2) Mean of the Market to Book Ratio (MBR) is 1.789. 3) There is a positive influence between the Debt to Equity Ratio (DER) towards the Market to Book Ratio (MBR). 4) Research hypothesis Ho admitted that the Debt to Equity Ratio (DER) has no significant influence towards the Market to Book Ratio (MBR). 5) There is a very weak correlation between the Debt to Equity Ratio (DER) towards the Market to Book Ratio (MBR) of 0.181. 6) There is no significant influence between the Debt to Equity Ratio (DER) towards the Market to Book Ratio (MBR) on the Company's Sub Sector Major Trade Goods Production which is Listed on the Indonesia Stock Exchange of 3.3 percent.

Keywords: Debt to Equity Ratio (DER) and Market to Book Ratio (MBR)

\section{A. PENDAhUluan}

\section{Latar Belakang Masalah}

Nilai perusahaan sangat penting karena mencerminkan kinerja keuangan yang dapat mempengaruhi penilaian para investor terhadap perusahaan. Investor yang akan memutuskan untuk melakukan investasi pada suatu perusahaan membutuhkan penilaian tentang saham. Menurut
Hartono dalam Hidayati (2010:13), terdapat tiga jenis penilaian yang berhubungan dengan saham, yaitu nilai buku (book value), nilai pasar (market value) dan nilai intrinsik (intrinsic value). Investor perlu mengetahui dan memahami ketiga nilai tersebut sebagai informasi penting dalam pengambilan keputusan investasi saham karena dapat 
membantu investor untuk mengetahui saham mana yang bertumbuh dan murah.

Salah satu pendekatan dalam menentukan nilai intrinsik saham adalah Price Book Value (PBV) atau juga dikenal dengan nama Market to Book Ratio (MBR). MBR digunakan untuk mengukur kinerja harga saham terhadap nilai bukunya. Perusahaan yang berjalan dengan baik, umumnya rasio MBRnya mencapai di atas satu, yang menunjukkan bahwa nilai pasar saham lebih besar daripada nilai bukunya.

MBR setiap perusahaan pada umumnya mengalami fluktuasi. Fluktuasi nilai MBR dipengaruhi oleh berbagai faktor. Menurut Brigham dan Joel (2011:155), salah satu faktor yang mempengaruhi nilai perusahaan dan harga saham yaitu struktur modal. Pengertian struktur modal menurut Halim (2007:58), adalah perimbangan jumlah utang jangka pendek yang bersifat tetap, utang jangka panjang, saham preferen, dan saham biasa. Oleh karena itu, struktur modal di-proxy dengan Debt to Equity Ratio (DER), yang merupakan perbandingan antara total hutang terhadap modal sendiri. Menurut Kusuma dalam Yuliana (2012:3), leverage merupakan hasil dari penggunaan dana dengan biaya tetap untuk saham.

\section{Rumusan Masalah}

Berdasarkan latar belakang yang telah diutarakan di atas, maka rumusan masalah dalam penelitian ini adalah sebagai berikut:

a. Bagaimana gambaran Debt to Equity Ratio (DER) dan Market to Book Ratio (MBR) pada Perusahaan Sub Sektor Perdagangan Besar Barang Produksi yang tercatat di Bursa Efek Indonesia?

b. Apakah Debt to Equity Ratio (DER) berpengaruh signifikan terhadap Market to Book Ratio (MBR) pada Perusahaan Sub Sektor Perdagangan Besar Barang Produksi yang tercatat di Bursa Efek Indonesia?

\section{Tujuan Penelitian}

Berdasarkan rumusan masalah yang dikemukakan di atas, maka tujuan penelitian ini adalah sebagai berikut:

a. Untuk mengetahui gambaran Debt to Equity Ratio (DER) dan Market to Book Ratio (MBR) pada Perusahaan Sub Sektor Perdagangan Besar Barang Produksi yang tercatat di Bursa Efek Indonesia.

b. Untuk mengetahui dan menganalisis signifikansi pengaruh Debt to Equity Ratio (DER) terhadap Market to Book Ratio (MBR) pada Perusahaan Sub Sektor Perdagangan Besar Barang Produksi yang tercatat di Bursa Efek Indonesia.

\section{Metode Penelitian}

Objek pada penelitian ini adalah Perusahaan Sub Sektor Perdagangan Besar Barang Produksi yang tercatat di Bursa Efek Indonesia dari tahun 2009 sampai dengan tahun 2013 dengan kriteria sebagai berikut: a. Perusahaan yang mempublikasikan laporan keuangannya yang telah diaudit secara berturutturut selama tahun penelitian.

b. Perusahaan yang tidak pernah mengalami posisi ekuitas negatif selama tahun penelitian.

Berdasarkan kriteria penarikan objek penelitian pada uraian di atas, maka diperoleh jumlah objek penelitian ini adalah sebanyak 24 perusahaan. Metode analisis yang digunakan untuk menguji hipotesis dalam penelitian ini adalah analisis regresi linier sederhana dan oleh karenanya uji asumsi klasik harus terlebih dahulu dilakukan. Uji asumsi klasik yang dilakukan antara lain uji normalitas, uji heteroskedastisitas dan uji autokorelasi. Teknik analisis data dalam penelitian ini menggunakan alat bantu software SPSS (Statistical Product and Service Solutions)

\section{B. LANDASAN TEORI}

1. Laporan Keuangan

Bagi pihak-pihak yang berkepentingan terhadap posisi dan kondisi keuangan, sangat membutuhkan informasi keuangan yang dapat diperoleh dari laporan keuangan. Menurut Martani, dkk. (2012:8), laporan keuangan adalah informasi keuangan yang dihasilkan oleh proses akuntansi. Laporan keuangan dapat digunakan untuk tujuan umum maupun tujuan khusus.

Sesuai dengan Standar Akuntansi Keuangan yang berlaku di Indonesia dalam Martani, dkk. (2012:10), laporan keuangan terdiri dari: Laporan Posisi Keuangan, Laporan Laba Rugi Komprehensif, Laporan Arus Kas, Laporan Perubahan Ekuitas, dan Catatan atas Laporan Keuangan.

Menurut Kasmir (2010:93), rasio keuangan merupakan kegiatan membandingkan angka-angka yang ada dalam laporan keuangan dengan cara membagi satu angka dengan angka lainnya. Rasio keuangan menurut Subramanyam dan John (2010:44), antara lain sebagai berikut: Rasio Likuiditas (liquidity ratios), Rasio Solvabilitas dan Struktur Modal, Tingkat Pengembalian Investasi, Kinerja Operasi, Pemanfaatan Aset (Asset Utilization), dan Ukuran Pasar (Market Measure).

\section{Struktur Modal}

Menurut Margaretha (2011:112), struktur modal (capital structure) menggambarkan pembiayaan permanen perusahaan yang terdiri dari utang jangka panjang dan modal sendiri. Kebijakan struktur modal merupakan trade off antara risk dan return. Utang meningkat, maka risk meningkat sehingga return pun meningkat. Apabila risk meningkat, maka harga saham turun, tetapi jika return meningkat maka harga saham naik.

Struktur Modal dalam penelitian ini diukur dengan debt to equity ratio (DER). Rasio DER digunakan untuk mengukur kemampuan perusahaan dalam memenuhi kewajiban dalam membayar hutangnya dengan jaminan modal sendiri. Selain itu rasio ini juga bisa digunakan untuk mengukur perimbangan antara kewajiban yang dimiliki perusahaan dengan modal sendiri. Secara matematis 
DER dapat dirumuskan sebagai berikut: Debt to Equity Ratio $(\mathrm{DER})=$ Total hutang / total ekuitas.

\section{Nilai Perusahaan}

Menurut Keown, et. al. (2004:470), nilai perusahaan adalah nilai pasar atas surat berharga hutang dan ekuitas perusahaan yang beredar. Bagi para pemegang saham, harga pasar saham perusahaan menggambarkan nilai perusahaan termasuk seluruh kompleksitas dan risiko dunia nyata.

Brigham dan Joel (2010:150), menyebutkan ada 3 rasio nilai pasar yang berhubungan dengan harga saham perusahaan terhadap laba, arus kas dan nilai buku per sahamnya. Rasio nilai pasar tersebut antara lain: Rasio Harga/Laba (Price Earning RatioP/E), Rasio Harga/Arus Kas (Price Cashflow Ratio$\mathrm{P} / \mathrm{C}$ ), dan Rasio Nilai Pasar/Nilai Buku (Market to Book Ratio-M/B). Rasio nilai pasar/nilai buku (M/B) = harga pasar saham / nilai buku per saham. Nilai buku per saham = ekuitas biasa $/$ jumlah saham beredar

\section{Pengaruh Struktur Modal Terhadap Nilai} Perusahaan

Kebijakan struktur modal merupakan trade off antara risk dan return. Utang meningkat, maka risk meningkat sehingga return pun meningkat. Apabila risk meningkat, maka harga saham turun, tetapi jika return meningkat maka harga saham naik. Karena itu, struktur modal yang optimal harus berada pada keseimbangan antara risiko dan pengembalian yang memaksimumkan harga saham. Sesungguhnya, tak seorang pun mengetahui bagaimana menentukan secara persis struktur modal yang optimal untuk suatu perusahaan, atau bagaimana mengukur secara tepat pengaruh struktur modal perusahaan terhadap nilai perusahaan maupun biaya modalnya (Brigham dan Joel, 2001:38).

Investor yang rasional akan memandang bahwa peningkatan nilai perusahaan berasal dari penggunaan utang yang tinggi. Menurut Sudana (2011:153), investor mungkin akan menawarkan harga saham yang lebih tinggi setelah perusahaan menerbitkan utang untuk membeli kembali saham yang beredar.

\section{PEMBAHASAN}

\section{Analisis}

a. Analisis Deskriptif Kualitatif

\section{1) Gambaran Debt to Equity Ratio (DER)}

Dari hasil penelitian, nilai DER maksimum Perusahaan Sub Sektor Perdagangan Besar Barang Produksi yaitu mencapai angka 14,38, artinya jumlah hutang lebih besar dari modal perusahaan tersebut. Dari hasil penelitian, angka 14,38 tersebut terdapat pada PT Intraco Penta Tbk pada tahun 2013. Untuk nilai DER minimum yaitu mencapai angka 0,02 atau dalam arti jumlah hutangnya lebih kecil dari jumlah modalnya. Dari hasil penelitian, angka 0,02 tersebut terdapat pada PT Akbar Indo Makmur Stimec Tbk pada tahun 2013.
Dari hasil penelitian, rata-rata nilai DER Perusahaan Sub Sektor Perdagangan Besar Barang Produksi periode 2009-2013 adalah tinggi yaitu sebesar 1,82. Angka 1,82 tersebut mengandung arti bahwa $182 \%$ rupiah dari modal pemilik digunakan untuk menjamin hutang.

\section{2) Gambaran Market to Book Ratio (MBR)}

Dari hasil penelitian, nilai MBR maksimum perusahaan yang termasuk Sub Sektor Perdagangan Besar Barang Produksi periode 2009-2013 mencapai angka 5,55. Angka ini ada pada PT Jaya Konstruksi Manggala Pratama Tbk pada tahun 2013. Dari hasil penelitian selanjutnya, diperoleh nilai minimum MBR yaitu sebesar 0,25 , yang artinya perusahaan tersebut dihargai sebesar $25 \%$ dibandingkan nilai bukunya. Angka 0,25 tersebut terdapat pada PT Perdana Bangun Pusaka Tbk pada tahun 2009.

Dari hasil penelitian, nilai rata-rata market to book ratio pada Perusahaan Sub Sektor Perdagangan Besar Barang Produksi periode 2009-2013 adalah sebesar 1,789, yang artinya perusahaan tersebut dihargai sebesar $178,9 \%$ dibandingkan nilai bukunya. Tingginya market to book ratio menunjukkan penilaian atau harapan investor terhadap perusahaan

\section{b. Analisis Deskriptif Kuantitatif}

Berdasarkan hasil analisa dengan program SPSS, maka model persamaan regresi adalah sebagai berikut: $\mathrm{MBR}=0,738+0,163$ DER $+\varepsilon$. Berdasarkan hasil persamaan regresi di atas maka dapat disimpulkan bahwa terdapat pengaruh yang positif antara Debt to Equity Ratio (DER) terhadap Market to Book Ratio (MBR) pada Perusahaan Sub Sektor Perdagangan Besar Barang Produksi yang tercatat di Bursa Efek Indonesia periode 2009-2013.

Berdasarkan hasil pengolahan data SPSS diperoleh nilai koefisien korelasi adalah sebesar 0,181 . Dengan demikian dapat dikatakan bahwa korelasi atau hubungan antara Debt to Equity Ratio (DER) terhadap Market to Book Ratio (MBR) pada Perusahaan Sub Sektor Perdagangan Besar Barang Produksi yang tercatat di Bursa Efek Indonesia periode 2009-2013 adalah sangat lemah. Untuk nilai koefisien determinasi adalah sebesar 0,033 yang berarti bahwa Market to Book Ratio (MBR) dapat dijelaskan Debt to Equity Ratio (DER) sebesar 3,3\% pada Perusahaan Sub Sektor Perdagangan Besar Barang Produksi yang tercatat di Bursa Efek Indonesia periode 2009-2013, sisanya sebesar 96,7\% dijelaskan oleh variabel lain yang tidak dimasukkan dalam penelitian ini, seperti Return On Asset (ROA), Return On Equity (ROE), Debt to Asset Ratio (DAR), dan Dividend Payout Ratio (DPR).

Hipotesis untuk menguji signifikansi koefisien persamaan regresi dirumuskan sebagai berikut:

a) Ho ditolak jika $t_{\text {hitung }}>t_{\text {tabel }}$ atau jika signifikansi $<$ alpha, artinya Debt to Equity Ratio (DER) berpengaruh signifikan terhadap Market to Book Ratio (MBR) pada Perusahaan Sub Sektor 
Perdagangan Besar Barang Produksi yang Tercatat di Bursa Efek Indonesia.

b) Ho diterima jika $t_{\text {hitung }}<t_{\text {tabel }}$ atau jika signifikansi > alpha, artinya Debt to Equity Ratio (DER) berpengaruh tidak signifikan terhadap Market to Book Ratio (MBR) pada Perusahaan Sub Sektor Perdagangan Besar Barang Produksi yang Tercatat di Bursa Efek Indonesia.

Dengan tingkat kepercayaan 95\%, alpha 5\% atau 0,05 , dan $\mathrm{n}=50$ maka derajat bebasnya adalah df sebesar alpha dibagi $2=0,05: 2=0,025$ dan $\mathrm{n}-2=$ $50-2=48$, diperoleh angka $t_{\text {tabel }}$ sebesar 2,01063. Sedangkan nilai $t_{\text {hitung }}$ adalah sebesar 1,277 dan nilai signifikansi adalah sebesar 0,208. Karena $\mathrm{t}_{\text {hitung }}<\mathrm{t}_{\text {tabel }}$ $(1,277<2,01063)$ atau sig. $>$ alpha $(0,208>0,05)$ maka Ho diterima, artinya Debt to Equity Ratio (DER) berpengaruh tidak signifikan terhadap Market to Book Ratio (MBR) pada Perusahaan Sub Sektor Perdagangan Besar Barang Produksi yang Tercatat di Bursa Efek Indonesia periode 2009-2013.

\section{Evaluasi}

\section{a. Debt to Equity Ratio (DER)}

Dari hasil penelitian, diperoleh rata-rata nilai debt to equity ratio (DER) pada Perusahaan Sub Sektor Perdagangan Besar Barang Produksi periode 2009-2013 adalah di atas 1 yaitu sebesar 1,82 yang berarti total hutang perusahaan lebih tinggi dari total modalnya. Angka 1,82 tersebut mengandung arti bahwa $182 \%$ rupiah dari modal pemilik digunakan untuk menjamin hutang.

Penelitian ini tidak membahas apakah tingkat rata-rata debt to equity ratio (DER) sebesar 1,8154 yang dihasilkan oleh Perusahaan Sub Sektor Perdagangan Besar Barang Produksi yang tercatat di Bursa Efek Indonesia sudah cukup baik dibanding dengan tingkat rata-rata debt to equity ratio (DER) di sub sektor lain yang ada di perusahaan perdagangan, jasa dan investasi pada periode yang sama.

\section{b. Market to Book Ratio (MBR)}

Dari hasil penelitian, diperoleh rata-rata nilai market to book ratio (MBR) pada Perusahaan Sub Sektor Perdagangan Besar Barang Produksi periode 2009-2013 yaitu sebesar 1,789. Hal ini menunjukkan bahwa rata-rata harga pasar saham perusahaan yang tercatat pada Perusahaan Sub Sektor Perdagangan Besar Barang Produksi adalah sebesar 1,789 kali dibandingkan nilai bukunya.

Penelitian ini tidak membahas apakah tingkat rata-rata Market to Book Ratio (MBR) sebesar 1,789 yang dihasilkan oleh Perusahaan Sub Sektor Perdagangan Besar Barang Produksi yang tercatat di Bursa Efek Indonesia sudah cukup baik dibanding dengan tingkat rata-rata Market to Book Ratio (MBR) di sub sektor lain yang ada di Perusahaan Perdagangan, Jasa dan Investasi pada periode yang sama.

\section{KESIMPULAN DAN SARAN}

\section{Kesimpulan}

a. Rata-rata Debt to Equity Ratio (DER) yang dihasilkan oleh Perusahaan Sub Sektor
Perdagangan Besar Barang Produksi yang tercatat di Bursa Efek Indonesia periode 20092013 adalah sebesar 1,82.

b. Rata-rata Market to Book Ratio (MBR) Perusahaan Sub Sektor Perdagangan Besar Barang Produksi yang tercatat di Bursa Efek Indonesia periode 2009-2013 adalah sebesar 1,789 .

c. Hasil persamaan regresi linier sederhana yaitu: MBR $=0,738+0163$ DER $+\varepsilon$. Hal ini menunjukkan bahwa terdapat pengaruh yang positif antara Debt to Equity Ratio (DER) terhadap Market to Book Ratio (MBR) pada Perusahaan Sub Sektor Perdagangan Besar Barang Produksi yang tercatat di Bursa Efek Indonesia periode 2009-2013.

d. Melalui perhitungan uji $t$ dengan taraf signifikansi 5\% disimpulkan bahwa $t_{\text {hitung }}<t_{\text {tabel }}$ $(1,277<2,01063)$ atau sig. > alpha $(0,208>$ 0,05) maka Ho diterima, artinya Debt to Equity Ratio (DER) memiliki pengaruh yang tidak signifikan terhadap Market to Book Ratio (MBR) pada Perusahaan Sub Sektor Perdagangan Besar Barang Produksi yang tercatat di Bursa Efek Indonesia periode 2009-2013.

e. Melalui analisis koefisien korelasi diketahui bahwa terdapat hubungan yang sangat lemah antara Debt to Equity Ratio (DER) terhadap Market to Book Ratio (MBR) pada Perusahaan Sub Sektor Perdagangan Besar Barang Produksi di Bursa Efek Indonesia periode 2009-2013 yaitu sebesar 0,181 .

f. Hasil koefisien determinasi adalah sebesar 0,033 atau 3,3\% yang berarti bahwa Market to Book Ratio (MBR) dapat dijelaskan Debt to Equity Ratio (DER) sebesar 3,3\% pada Perusahaan Sub Sektor Perdagangan Besar Barang Produksi yang tercatat di Bursa Efek Indonesia periode 20092013, sisanya sebesar $96,7 \%$ dijelaskan oleh variabel lain yang tidak dimasukkan dalam penelitian ini seperti Return On Asset (ROA), Return On Equity (ROE), Debt to Asset Ratio (DAR), dan Dividend Payout Ratio (DPR).

\section{Saran}

a. Sebaiknya perusahaan dalam menentukan struktur modalnya tidak sepenuhnya dibiayai dengan hutang. Penggunaan hutang yang terlalu besar juga akan menyebabkan perusahaan akan semakin terbeban dalam pembayaran beban bunga sehingga akan menimbulkan risiko kebangkrutan yang semakin tinggi.

b. Sebagai bahan masukan untuk penelitian selanjutnya, perlu memperbanyak variabel penelitian yaitu rasio struktur modal yang tidak dibahas di dalam penelitian, seperti Debt to Asset Ratio (DAR), Long Term Debt to Equity Ratio (LDER), Long Term Debt to Asset Ratio (LDAR) dan Times Interest Earned atau rasio-rasio keuangan yang lain seperti Return On Asset, Return on Equity, Gross Profit Margin, Net Profit Margin, Dividend Payout Ratio (DPR). 


\section{E. DAFTAR PUSTAKA}

Brigham, Eugene F., dan Joel F. Houston, 2001, Manajemen Keuangan, Edisi Kedelapan, Buku 2, Jakarta : Erlangga.

Brigham, Eugene F., dan Joel F. Houston, 2010, Dasar-dasar Manajemen Keuangan: Essential of Financial Management, Edisi 11, Buku 1, Jakarta : Salemba Empat.

2011, Dasar-dasar Manajemen Keuangan: Essential of Financial Management, Edisi 11, Buku 2, Jakarta : Salemba Empat.

Halim, Abdul, 2007, Manajemen Keuangan Bisnis, Bogor : Ghalia Indonesia.

Hidayati, Eva Eko, 2010, Analisis pengaruh DER, DPR, ROE dan Size Terhadap PBV Perusahaan Manufaktur yang listing di BEI Periode 2005-2007, Semarang : Universitas Diponegoro, Tesis.

Kasmir, 2010, Pengantar Manajemen Keuangan, Edisi Pertama, Cetakan Kedua, Jakarta : Prenada Media Group.

Keown, et. al., 2004, Manajemen Keuangan: Prinsip- prinsip Dasar dan Aplikasi, Edisi Kesembilan, Jilid 1, Jakarta : PT. Indeks Kelompok Gramedia.

Margaretha, Farah, 2011, Manajemen Keuangan Untuk Manajer NonKeuangan, Jakarta: Erlangga.

Martani, dkk., 2012, Akuntansi Keuangan Menengah Berbasis PSAK, Jakarta : Salemba Empat.

Subramanyam, K. R and John J. Wild, 2010, Analisis Laporan Keuangan : Financial Statement Analysis, Buku Satu, Edisi Sepuluh, Jakarta : Salemba Empat.

Sudana, I Made, 2011, Manajemen Keuangan Perusahaan : Teori dan Praktik, Jakarta : Erlangga.

Yuliana, Tanti, 2012, Analisis Pengaruh DER Dan Intensitas R\&D Terhadap Nilai Perusahaan (Studi Pada Perusahaan Manufaktur yang Terdaftar di Bursa Efek Indonesia (BEI) Periode Tahun 2008-2011), Surabaya : Universitas Negeri Surabaya, Jurnal Online. 